\title{
翻刻 北村喜八作「ユージン・オニール」
}

Kihachi Kitamura, “Eugene O’Neill”:

A transcript of a radio play

\author{
山名 章二1 \\ 1大妻女子大学 \\ Shoji Yamana ${ }^{1}$ \\ ${ }^{1}$ Otsuma Women’s University \\ 12 Sanban-cho, Chiyoda-ku, Tokyo, Japan 102-8357 \\ キーワード：北村喜八，ユージン・オニール，啓蒙的評伝，ラジオ劇
}

Key words : Kihachi Kitamura, Eugene O’Neill, Basic critical biography, Radio play

\section{抄録}

これは草稿転写の報告だが，解読に詰めも残しており，資料の紹介ノートと呼ぶのがふさわし い. 原本は日本放送協会のラジオ放送劇の脚本で，金沢市在石川近代文学館に北村喜八関連資料 の一として所蔵されている．放送は日本の連合国軍への降伏からほぼ三年後，1948年8月であった. 築地小劇場に始まり演劇界で広範に活躍し, 英米さらにドイツの文学作品を幅広く翻訳出版, 数 多の著書を公刊，晚年には日本の劇界を代表して国際的に活動し，その中でオニールにも上演に 翻訳に深く取り組み続け, 文通もあった北村喜八の執筆による．その内容はオニールが波乱の青 年期を終え演劇に確固たる基盤を築く頃をセリフ劇形式で跡付け，その後の主要戯曲および近作 情報を紹介し，オニールの一層の活躍への期待も込められている．1946年初演の The Iceman Cometh はいち早く触れられているが，没後25年を経て公開するよう遺言されることになる Long Day’s Journey into Night への言及はない, 当然ながら.

アメリカ文化に大いに関心を寄せその影響も色濃い1920年代，30年代の日本がアメリカ演劇を 受容した熱気を戦後に復興しようとする意欲をも窺わせる資料である.

\section{はじめに}

本翻刻は石川近代文学館所蔵の「北村喜八自筆 脚本原稿『ユージン・オニール』」を底本とする。

訂正加筆插入は徒らに整理せず再録に努めた. 解読次第ながら，執筆の深層を窥わせることもあ るからだ。その意味でも, 誤字, 誤緅, 単純な書 き損じと想われる場合も，忠実に転写し，（ママ） と書き添えてその旨を示した.

また，旧仮名遣いは言うまでもなく，旧漢字は 再現に努めた。確立していたと思われる略字はそ のままにし, 後に新漢字として認められる略字く ずし字の併用も推測された場合は，旧漢字に統一 した.
そして，解読が困難な場合は一字単位で $\square に$ 代 え，また，抹消の意向が明らかな場合，解読可能 な箇所は再現し，不可能な場合は $\square$ を当てた後， それぞれに打ち消し線を重ねた。さらに，改筆加 筆部分は文字数に拘らず前後を〔 の のように囲 った. 手書きならではの自由な訂正挿入について も同様に表記した。なお，欄外の書き込みは各葉 の初頭に書き添えた。解読が詰めきれない場合は, 該当箇所の後に（?）を添えその旨を記した.

本来の縦書きを横書きに, 句点読点は本ジャー ナルの書式に従いピリオドとカンマに換えた.

正確を期す場合は原本に当たられたい. 
[ ] [別人の筆による第一葉は羁線のないタテ $17 \mathrm{cmX}$ ヨコ $24 \mathrm{~cm}$ の用紙に，まず，放送局名，放送日時， 番組名, 企画タイトル，そしてこの回の内容が記 されている，ついで，おそらく放送時のスタッフ の作業に対寸る指示らしきものを交えて，担当ア ナウンサーに宛てた番組紹介文が続く.

興味深いことに, 番組シリーズ内の順位を示寸 部分が空白のまま残されている。 J

第一放送〔続いてエンピツで 23年 と付記あり〕 八月十一日（水）后五. 三○一 六. $\bigcirc \bigcirc$ 学生の時間

$$
\begin{aligned}
& \text { “ノーベル賞に輝く人々” } \\
& \text { 「ユージ・オニール」 } \\
& \text { 北村喜八作 } \\
& \text { X X X X }
\end{aligned}
$$

$$
\begin{aligned}
& \text { テーマ 上・・・下・・下にもつ } \\
& \text { アナ 学生の時間が参りました } \\
& \text { テーマ 上・・・下・・・下にもつ }
\end{aligned}
$$

アナ 毎週水曜日のこの時間は「ノーベル賞に輝く 人々」について御紹介して参りました

今日はその $\square$ 回目と致しまして北村喜八作 「ユージン・オニール」をお送り致しませう

$$
x \quad x \quad x \quad x
$$

[ ]〔次いで「脚本」自体になる.用紙は1行20字，1 頁 20 行, 400 字詰, タテ $18.1 \mathrm{cmX} コ コ 25 \mathrm{~cm}$ の縦書き 原稿用紙である。しかし，その第一葉に当たる最 初の一枚には数字の書き入れがない，そして，次 葉以降, 改めて脚本の対話部分からなる延心゙三十 葉が順次番号を振り当てられて続く。」

八月十一日 (水) 后五. 三 $\bigcirc-$ 六. $\bigcirc \bigcirc$ 第一 学生の時間

$$
\begin{array}{r}
\text { “ノーベル賞に輝く人々” } \\
\text { ユージン・オ } \\
\text { 北 村 喜 八 }
\end{array}
$$

話し手一，船員，ウェブスター（俳優）。
話し手二，オニールの父，ジョージ・クック． 話し手三，ジミー坊主，ラティマー。

話し手四, オニールの兄.

ユージン・オニール

母 — オニールの母，スザン・グラスペル.

\section{[ 11$]$}

音楽.

話し手一 一九一一年 ——ューヨークの波 止場に「ジミー坊主」といふ酒場があった。荒 くれた船乗りや波止場人足を相手のもぐり酒場 である．酒場にすぐ續く奥の部屋では，ビール を大コップで一杯ものめば，テーブルにもたれ て 眠りながら一夜を明かすこともできるし， 街の淫売をつれこむこともできるといった風の ところである。酒場の主人はジミー坊主といふ 綽名のいかにもふさはしい男だ。青白い，ほっ そりした，䯿のない顔，柔和な青い眼，白い髪， それには前掛よりも僧侶の衣のほうがずっと似 合ひさうである。彼の口のきき方や物腰から して，誰でも彼をこの波止場の顔役だと思ふに ちがいない。言葉づかいも，物腰も，穏やか で，もの静かである—しと〔が，〕この柔 和な影には，假面の下にかくれた彼の人亡なり — 皮肉で, 苛

[ 2 ] [右半分の上縁に筆記体で (以下同じ) Eugene O’Neillと記されている]

酷で，石のやうに冷酷な人間を感じることがで きる。

話し手二 この酒場に, 背の高い一人の青年が ぶらぶらしながら暮らしてみる。ほっそり として背が高く，針金のやうに強勒だが，その 物腰は，少内気で，神経質で，いつも當 惑してみるやうであり，その眼は絶えず果しな い夢を追ってみるやうに見える。これが當時二 十三になった放浪時代のユージン・オニールで ある。

汽船の警笛の音— 時々きこえる.

話し手一ジミー坊主はスタンドの向うに腰を おろし，眼鏡ごしに夕刊をよんでみる. ユージン（はいってきて）只今. 
話し手三（ジミー坊主） ああ，ジエンか、今 夜は馬鹿に早いぢゃないか。仕事にあぶれたの かい.

ユージン いや, 河岸を 〔ほっ〕つき备 っていたんだ.

\section{[ 3 ]}

ジミー坊主＼cjkstart何かころがってみたかい・・・ど えらい好運でも。

ユージン [ぼく〕は船乗り相手に海の話 をしたり，青い海の向うの水平線をぼんやり眺 めてみたりするのが好きなんだ。ぼくあ，また 船に乗りたくなったよ。

ジミー坊主 お゙ゃ乗るさ。・・・・

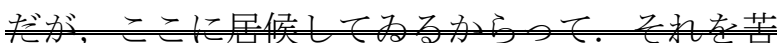

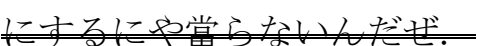

警笛.

ユージン 警笛の奴，いやに唸りあがるな.・

・・・今夜はとても梁い霧だぜ，ジミー。

ジミー坊主ささうかい.

ユージン どこもかも蒙々と烟ってみて, 船の

灯がロっやによ光ってみるだけ だ.

船員が一人はいってくる.

話し手一（船員）よう，今晚は。

ジミー (ママ以下同様) （口愛嬌をふりまいて）

シップ・アホーイ！ いい航海だった

\section{[ 4 ]}

かい。

船員有難——〔う〕。まあ，一杯くれ。

ジミー（口〔職〕業的に）何にいたしやし ようか。

船員 ウイスキーをもらはう・・・・アイリッ シュ・ウイスキーだ.

ジミーへい.

船員 ジミー坊主ってお前さんのことかい.

ジミー へえ，さやうで.

船員＼cjkstart実は船乗りがひとり至急にほしいんだが， 誰かみないかね。

ジミーお前さんどうしてここへききにおい でなすったんだね.

船員急場の用ならジミー坊主のとこへ行って
みろって言はれたもんでね.

ジミーなるほじ.

船員 あした，サザンプトン行の船が出ること になってるんだが，船員が一人，急に病気にな =りやが二ったもんで困ってみるんだ.

\section{[ 5 5 ]}

ユージン＼cjkstart僕が行きませう．

船員＼cjkstart君が・・・・君は船乗りがやれるの かい.

ユージン＼cjkstart僕は船から下りたばかりですよ。

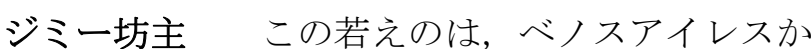

らイギリスの不定期船で帰ってきたばかりなん

だ。おれが保證するよ。

船員何だってまた南米口〔くんだり かけたんだ=廿二〔ね〕？

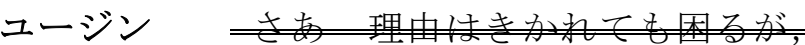

〔なにね，〕行きたくなって行ったまでだよ。

見知らぬ土地が見たくなって，家を飛びだして 船に乗ったまでなんだ。

船員無鉄砲な奴だな.

ユージン おかげで，向うお゙ゃさんざん苦労し ましたよ. ベノスアイレスロアルゼンチンで, 電気会社で働いたり，羊毛の運送店につとめた り，ミシン会社の外交員になったり，いろんな 商賣をやったが，とう口落ちぶれで，ベンチの 上で寝るって始末さ。

\section{[ 6 ]}

そこでまた〔ぞろ〕船に乗ってこっちへ舞い戻 ったってわけでさあ.

船員 ぢゃ，君は会員證を持ってみないんだら うな?

ユージン いや，持ってみますよ。これでさあ.

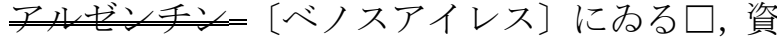
格をえたんだ。海の生活がすっかり気に入った もんですからね。

船員 お゙ゃ，おれの船へ来てくれるかい。

ユージン じうだらうね，ジミー。

ジミー坊主お前がその気なら行った方がいい ぜ。

船員船は「ニューヨーク」号だ。イギリスの サザンプン〔ママ]へ行くアメリカ定期船だ.二 
番ドックに碇泊してみるから，すぐ分かるよ．

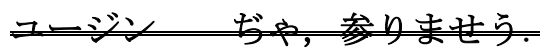

警笛の音. 寂しくかすれて行く.

話し手二 これがオニールの二番回目の，そし て最後の, 船乗り生活であった.

\section{[ 7 ]}

\section{ジャズ風の音楽。}

話し手二＼cjkstart翌年，船から戻ったオニールは，ま たジミー坊主の酒場でごろごろしてわた，その 中，思ひがけないことで多少まとまった金が手 にはいったので，飲めや騒げやのランチ気騒ぎ につかってしまった.

音楽. 汽車の走る音に変ってゆく.

話し手一 ふと目がさめると，才ニールは汽車 の中に眠ってるる自分を發見した。

オニール（暗く）おれは何だって汽車なんか に乗ってみるんだ. 酔っぱらった揚句に乗った ものと見える.は沏符を買ったかな？…・ あッ，あるある！ ニューオーリンズ・・・・ 何だってこんな遠くまでの切符を買ったんだ?

汽車の停る音. 雜沓.

話し手一＼cjkstart列車はニューヨークニューオーリン ズ直通の列車であった。オニールも仕方なしに ニューオーリンズの駅に下りる。

[ 8 ] [左半分上縁にJames O’Neill / Monte Christo（マ マ) / Ella Quinlan と記されている]

雨の音.

話し手二＼cjkstart春にはまだ早い冷たいミゾレまざり の雨が降ってみる.オニールはあたりを見廻し た。芝居の大きなポスターがふと目についた。 見るともなしに見ると，ジェームズ・オニール 主演，モンテ・クリスト・・・・

オニール なあんだ。親父はこんなところで巡 業してみたのか。 こいつあ全く偶然だ。よし， ニューヨークまで歸る旅費をせびってやらう. 音楽.

話し手三オニールの父のジェームズ・オニー ルはアイルランドの出身で，當時一流のアメリ カの俳優であった。 ハムレットやオセロを演じ てもうまかったが，デューマの「モンテ・クリ スト」 =@=〔を〕ヴォードヴィル風に脚色した
ものを演じて大當りをとってからは，それをも ってアメリカ全土を巡業してみた。母のエラ・ クインランはアメリカ

\section{[ 9 ] [左半分上縁にBetts Academy at Stamford と記さ} れている]

中西部の生れで，女学校時代から美しい娘で, ピアノが上手であった。しとやかな，信心深い 性質だったので，父と結婚してからも， 父と一しょに巡業して歩いてみたが，決して舞 台の仕事に関係しようとしなかった。

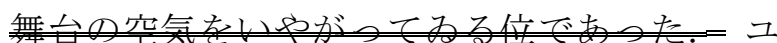
ージン・オニールは一八八八年十月，ニューヨ ークで生れてみる. ジムといふ十才年上の兄が ある。兄弟は幼年時代，父の巡業に伴はれて， 殁じアメリカ全土を巡業して歩いて子 〔た〕．オニールは七つの時，カソリックの小 学校へはいった。 そこの寄宿舎で六年を過ごし た。一九 ○年，コネロティカット州の港町で あるスタムフォードのベッツ・アカデミ (ママ) に入学した。一九○六年, そこを卒業して，そ の秋プリンストン大学へはいった。しかし, 夢 想的で，熱情的丸こ抄少飞飞って，大学生活 彼は一年でそ こを飛び出した。十九の時

\section{[ 10$]$}

である。年の時から彼の族浪の生活がはじまる のであ.

話し手一 大学を飛び出した彼は，父の関係し てめるニューヨークの通信会社にしばらくつと めた。しかし，間もなく，或る鑛山技師につれ だって，中央アメリカのホンデュラスの金鑛探 險に出かけた。六ヶ月の終りに，一攖千金の夢 は空しく破れて，彼はひどいマラリアに冒され て歸ってきた。そして，父の許へ歸った彼は， 父の劇團のマネヂャーの助手をしながら，東部 から中西部へと巡業して迴った。しかし，その 生活も長く續かなかった。コンラードの海の小 説「ナーシサスの黒ん坊」を讀んでるるうちに, 夢みがちなこの少年の心は，遠く海の上へ引き つけられて行った，彼は又しても父の許を飛び だして，ノルウェーの帆前船に身を投じてべノ 
スアイレスへ行った。転々たる放浪の生 活・・・・

音楽.

\section{[ 11 ]}

話し手三 そして今，思ひがけなく，父の巡業 先であるニューオーリンズへ来たのである.

話し手二 侘しい雨の降る楽屋は・・・・オニ 一ルは，はかりかねて，ふと佇んだ。

話し手四（ジム） おい，ジェンお゙ゃないか.

どうしてこんなところへ来たんだ.

話し〔オニ〕ール ああ, ジム兄さん・・・・

ジム お前, 馬鹿にしょげ返った顔をしてるる なあ.どうしたんだ?

オニールお父さんに，ニューヨークへ帰る旅

費をかりようと思ふんだ.

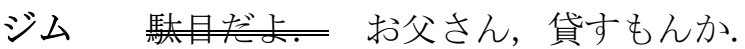

オニール だって, 兄さんだってよくやるお゙ゃ ないか.

ジム お父さんは今，舞台だ。僕は自分の役が すんだんで，一寸宿へかへらうと思ってみたと ころだ. 一しょに行かう. お父さんに會ふ前に, お母さんに會った方がいいぜ.

\section{[ 12 ]}

音楽.

母 まあまあ, ジエンぢゃないか. よく帰って おいでだねえ。

ユージン しばらくでした。〔お母さん，〕お 変わりもありませんか。

母 一体，お前，どこで何をしてみたんだね.
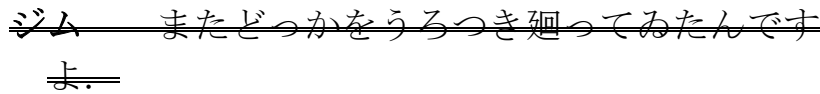

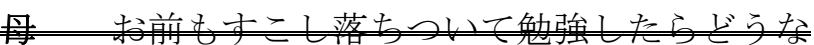

もう一度大学へ戻る気はないのかい。 お父さんもお前が大学を卒業してくれるのを， どんなに望んでいらっしゃるかしれないんだ よ.

ユージン 僕, 大学にもう興味がないんで す.・・・皁れよりお母さん，ピアノをひい てきかして下さい.

母 どうして突然そんなことを言ひ出すんだ ね. $\begin{array}{ll}\text { ユージン } & \text { 僕, =船=〔海〕の上で時々お母さん } \\ \text { のピ }\end{array}$

\section{[ 13 ]}

アノの音を思ひ出したんです.

ジム おい，ジェン，お前また船に乗ってたの かい.

オニールアメリカ定期船にのって，サザンプ トンまで行ってきたよ。海員の資格もとった よ.

ジムぢや，一そ船乗りにでもなるといいん だ.

母 まあ，お前ったら，世界〔中〕をあっちこ

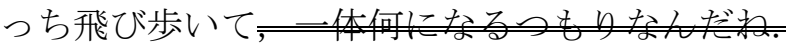
$[\cdot ・ \cdot \cdot]$

話し手一＼cjkstart父は劇場から帰ってきた。

話し手二（父）〔お父さん]はお前の 常軌を逸した生活を見てるると，どうしたって 気狂ひとしか思へない，お前をどう扱ったらい いのか分からないんで，お父さんはほとほと思 案にあまってみるよ．お前には何か人と変わっ た特別の才能があるのかもしれない.しかし， お父さん〔として〕は，お前が落ちついて，何 かきまった職業についてくれたらと思ふ

\section{[ 14 ]}

よ.

ジムお父さん，ジェンはニューヨークへ帰る 旅費をほしがってみるんです。

父そりや旅費くらみやってもいい上飞〔さ〕。 やってもいいが，また放浪して歩くのが関の山 だらう。・・・・おい，ジェン，お前がニュー ヨークへ帰りたいんなら，自分で稼いで旅費を つくるがいい。でなければ，お父さんの一座に はいって, しばらく落ちついたらどうだ. 汽車の音.

話し手三＼cjkstart汽車はコロラード山脈を越えて，ユ タ州のオグデンへ向かって〔西へ西へと〕走っ てみる，列車にはジェームズ・オニールの一座 が乗ってみる. 小さな役を振られたオニールは, 座席の片隅で一心に台本を讀んでみる.

ジム どうだ，ジェン，セリフが覚えられたか. オニール 〔のてと，それ 
がね，すっかり]覚えたつ

\section{[ 15 ]}

もりなんだが，いざ舞台に立った時に覚 〔す らすら出てくる]かどうか自信がないんだよ. 話し手一 なに，大丈夫でさあ。配するこた あありませんよ。

オニールウェブスターさん，あなたは舞台の 経験が長いから，そんな風におっしゃるが，何 しろ僕〔に〕は初めてですからね。市なだ一 つの芝居で三つも〔ちがうん〕役を受け持って みるんで驚きましたよ。

ウェブスター すこし馴れりや何でもありませ んよ. それに，いくら一流の一座でも，むや みと人数が多くちゃ，旅興行は成り立たないか ら仕方がありません」〔や〕 。

オニールなるほどね.

ジム どうだい，ジエン，お前も兄さんのやう に，お父さんの一座で役者になってかいか [なる気はないかい]。

オニールしかし，こんな芝居をやってみるん ぢゃ詰まらないなあ。こさへもので, 嘘つぱち で・・・・

\section{[ 16 ]}

ジム生意気言う斌え。

オニール 僕は芝居ってものは，人生のもっと真 実な姿をかいたもんでなくちゃ意味がないと思 ふんだ.

ジム お゙ゃ，お前がさういうのを書いてみる さ. 列車の音，音楽へ変わる.

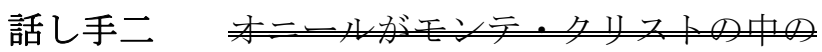

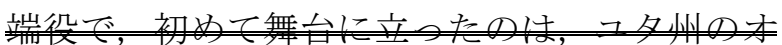
グデンでってそれから四ヶ月，父の一座に 加はって西部太平洋海岸を巡業して歩いた。五 月，シーズンの終わりとともに，オニールは父 の夏の別荘のあったコネチカット州のニュー・ ロンドンへ落ちついた。

話し手一＼cjkstart彼はこの町でテレグラフといふ新聞 の記者になった．編輯長をしてみたのが，フレ ーデリック・ラーティマー（ママ 以下同様）と いふ男であったが，彼はこの夢想的で，激しい
気象（ママ）の青年を愛した。暇さへあれば議 論を

\section{[ 17 ] [左半分上縁にWallingford と記されている]}

闘はし，またいろいろの書物をかしあたへた。 話し手三（ラーティマー）＼cjkstart君は人生や社會に たいして過激な思想をもってみるやうだ。わた しは君の考へには反対だが，君の考へは，人生 に対して求めるところが多く，而も人生からう ちひしがれたところから来たのかもしれない. 君は何かをもってみる，ひとつ小説でも書いて みたらどうだ。傑作が出来るかもしれないよ。

音楽. —— 爆発的で狂燥的なものか ら，急に静かなものに変る.

話し手二 その年の十二月，オニールは健康を 損ねて倒れた。医者から結核の徵候あり之宣告 された。大学を飛び出した十九の年から発病し た二十四の年までの，足かけ六年間の無軌道な 放浪生活が，健康を虫ばんだ（ママ）のである. コネチカット州のウォリングフォードのサナト リウムへはいったのが，クリスマスの前位であ った.

\section{[ 18 ] [左半分上縁にRippinと記されている]}

話し手三＼cjkstart六ヶ月の療養生活は，彼に深い内省 の時を与へた。彼は〔放浪時代に〕さまざまな 人間の，さまざまな生活を見た——彼らが苛酷 な世間に對するときの偽善的な態度や假面だけ でなく，そのかげにかくされてみるそれぞれの 思想や眞実な〔心の]姿を.「君は小説でも書 いてみたらどうだ」—ーラーティマーのさう言 った言葉が耳の底でひびく，父の舞台が目の前 にちらつく.・・・・

オニールささうだ, 脚本を書いてみよう・・・・ そこから自分の才能を見つけることができるか もしれない.

遠い波の音を，ずっと聞かせる。

話し手一ロング・アイランドの海峡に臨んだ， リッピンといふイギリス人の家庭がある。退院 したオニールはそこに寄寓して療養生活につと めた，入院する前の彼と [くらべると〕そ れは別人のやうであった。手に負へない浮浪の 少年も，今は，己の夢想と情熱を内面生活に注 
いで，静かな規則正しい生活を

\section{[ 19 ]}

おくる大人に生れ変わってるた.

話し手二＼cjkstart彼は手当り次第に讀書した，ギリシ ヤ古典劇, シェイクスピア劇, そしてイプセン やストリンドベリーをはじめとするあらゆる近 代劇〔作家〕の作品，からした讀書のかたはら， 彼は夢中になって創作に没頭した。

話し手一 水泳の上手な彼は，寒い冬でも泳ぐ のを日課にし，また夜はベッドを野外に持ち出 して寝るのを習慣にした。

話し手三 かうして，一年間の療養生活に書い た戯曲が，〔十数篇に達した。〕三幕物十二,長

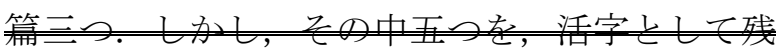
七, 支破育してみる.

この辺から波の音なし.

話し手一戯曲の原稿は父の出版屋へ送られ た.

話し手三＼cjkstart俳優の子供の書いた脚本に碌なのが あるもんか。

[ 20 ] [左半分上縁にBakerと記されている]

話し手一 出版屋はさう言って取り合はなかっ た.

話し手四 そこで彼は自費出版を思ひ立って， 父にその費用をたのんだ.

父父さんは買手のない脚本を書いても仕様が ないやうに思ふんだが何だってまた船 乗りのこんな污らしい生活ばかり書くんだねえ. しかし，お前の病気がなほって長生きするなら， 何とか物になるかもしれない.

話し手四 かう言って父は自費出版の費用を出 してくれた．新しいアメリカ戯曲の開拓者とし てのオニールの〔處女〕戯曲はかうして出版さ れた。一九一四年，「飢口その他の一幕もの」 と題するのがこれである。しかし，それは殆ん ど買手がなかった。

話し手三 当時ハー ※゙-[ヴァ]ート (ママ) 大 学には, ベーカー教授の指導する〔演劇科があ った．]有名な四十七番教室というのがそれで ある。オニールは一九一四年の秋，そこへはい
[ 21 ] [左半分上縁にWharf Theatreと記されている]

て，一年間本格的な劇作の勉強をした. 音楽.

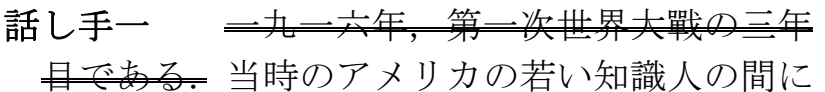
は, アメリカ演劇を〔して〕ヨーロッパの模倣 的性格から脱 —[せしめ]て新しい近代劇を 打ち建てようとする気運がウツボツとし浱って みた。 ニューヨークのグリニッチ・ヴィレージ に集まる若い藝術家の一群が，〔夏，〕マサチ ユセッツ州のプロヴィンスタウンといふ漁村に あつまって，自分たちの作品を自分たち の手で演じる計畫を立てた.

話し手三＼cjkstart波打ちぎわに建ってみる小さな魚置 き場の小屋を改造して, 彼らの実験劇場とした.

「波止場劇場」といふのがこれである.

話し手四一九一六年の夏, トランクに自作 の原稿を一ぱい詰めこんで，この素人劇場を訪 れた青年がある。ユージン・オニールである.

[ 22 ] [右半分上縁にGeorge Cram Cook / Susan Glaspell と記されている]

波の音.

話し手 $=\underline{\underline{\underline{\equiv}}}=$ 〔四〕この劇團の中心人物はジョー ジ・クラム・クックといって，四十をすこし出 た，大きな男であった。活動的で，忍耐強く，い つも一座のものを鼓舞してみた．夫人のスザ ン・グラスペルは三十位で．既に劇作家として 名を現はしてみた.

〔話し手四(ママ) 一九一六年の夏・・・・ 波の音，大きくなり，時々蒸汽船の 音.

話し手二（クック）䘛え，オニール君，これ がわれわれの実験劇場だよ。波止場劇場って名 前をつけたんだ。 $\square$ 前，魚の置き場に使ってみ たんだが，去年の夏，みんなで劇場に改造した のさ。僕自身，カンナとノコギリをもって働い たよ。・・・・これが舞台だ。間口十二フイー ト，奥行十フイート．客席の木の椅子は七十ば かりあるかな。・・・・全くの粗末な小屋だが, われわれはここから新しいアメリカの演劇を生 みだす意気込みでめるんだ。君の脚本もこの舞 
台で初

[ 23 ] [右半分上縁にBound East for Cardiff と記されて いる]

めて脚光をあびるわけだ.

オニール はあ.

グラスペル キランクに=自作の脚本を〔トラ

ンクに］一ぱい詰めて[こんで]いらした 凤

[って噂のあるの]はあなたでしたか.

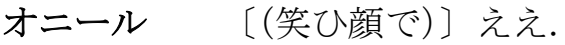

グラスペル 今度, あたしたちがここでやるこ

とになった「カヂフをさして東へ」は，あなた

の一番自信のある〔お〕作品ですか.

オニールさむ。，一番自信があるかときかれる

と困りますが，自分で先〔は〕気に入ってみる

作品の一つなんです。全部讀んでいただくのも

大変ですだと思ひました〕からと思いまし

たから，取りあへずあれをお目にかけたんで 寸.

グラスペル あたし，あれを拜見して，本当

に新鮮な感じがしましたわ。

オニール 有難う.

クックこの舞台は粗末だが，君の海の戯曲を

上演するには 持っていののる〔全く 打ってつけだ〕よ，空をあければ海が一目に見 えるし，満潮になれば，波が建物の前を洗ふし= 波 $[\cdot \cdot \cdot ・]$

\section{[ 24 ]}

オニール おや，こんなところからしぶきがあ がってみますよ・・・・床のすき間から.

クック 〔グラスペル〕満潮で浪の荒い日に

は，お客さんの足元の濡れることがあるんです よ。

クック ねえ, オニール君, 霧の深い日にはプ ロヴィンスタウンの港から 汽 [警]笛がきこ えてくるんだよ。そんな日にでも君の脚本を上

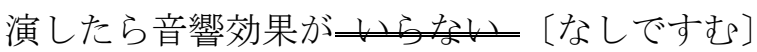
つてわけだねえ。

オニール＼cjkstart偶然といへば偶然でせうが，こんな 似つかわしい雾囲気の中で，あなた方のやうな 熱心な方々の手で，僕の脚本が上演されるのは 本当に幸福です。
グラスペルオニールさん，あなたも一役買っ て舞台へお出になりませんか.

オニール ええ, やりませう。

クック 君の脚本は全く人生の生告なまし い一片を引きちぎってきたやうな感じだ。僕は これからの戯曲はかういふ方向へ向っ

\section{[ 25 ]}

て行かなきやならないやうに思ふんだ。さうい う意味で, 今度の 舞台〔上演〕はアメリカ演劇 の歴史にとって記念すべき舞台になるだらうと 思灾よ。

静かに音楽がはいってきてみる.

話し手四 一九一六年夏，彼の「カヂフをさし て東」へが（ママ）プロヴィンスタウン劇團に よって上演され，オニール自身も二等運轉士の 役を演じた. それ以来, 彼の一幕ものは次々と 若い劇団の手で上演された.

話し手三彼は内気で，神経質で，孤独を愛す る藝術家である。よほどの余儀ない場合の外， レストランで食事をすることさへ稀であった. 彼はプロヴィンスタウンにあ

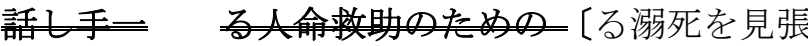
るために建てられた］古い小屋に住んで，執筆

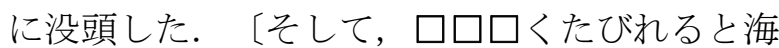
へ飛びこんで泳いだ. ] 一枚の毛布にくるまり， 足元に石油ストーヴをおいて，ペンを走らせる 若い日のオニールの姿がそこにあった。かつて はあんなに乱暴に酒をのんだ彼も，

[ 26 ] [右半分上縁にmorosco（ママ）及び Beyond the Horizonと，左半分上縁には Emperor Jones （ママ）と記されている]

執筆にあたっては一滴の酒も口にしなかった. 話し手一 一九二○年, 最初の長篇戯曲「地平 のかなた」がニューヨークのモロスコ劇場で初 演された。それはアメリカにおける近代的リア リズム手法による初めての長篇戯曲として，ア メリカ演劇にとって記念すべき作品である.

話し手二ついで同じ年ニューヨークでプロヴ インスタウン劇団によって初演された「皇帝ジ ヨーンズ」は，文明社会に生活した一人の黒人 の潜在意識を取りあつかひ，一種の一人芝居の 
形式をとった，主觀的傾向のつよい作品で，才 ニールの劇作家としての地位を確固たるものに した.

話し手三 オニールの戯曲の強味は, 人生その ものの生きた姿を舞台へ持ちこんだことである. 從って，セリフは乱暴な俗語の類をどしどし取 り入れ，生きいきとした力強いリズムと躍動感 をもってみる。

\section{[ 27 ] [右半分上縁にAnna Christie / Hairy Ape / All} God's Chillun Got Wings / Desire under t he Elms / Strange Interlude / Mourning Becomes Electra と記 されている]

話し手四「「アナ・クリスティ」「毛猿」「す心゙ ての神の子 〔に］翼あり」「榆の木かげの愛 慾」，次々と問題作を提供し，彼自身，世界的 レベルへ肉迫するとともに，アメリカの演劇の ために大きな道を切り開いた. 新しい作家たち は彼のあとに續いて續々と登場してきた。

話し手一 一九二八年の「奇妙な幕間狂言」, 一 九三一年の「喪服の似合ふエレクトラ」にいた って, 彼は高〔藝術家として円熟の]頂点 に達した。

話し手二 「奇妙な幕間狂言」は二部九幕から 成る大作で，三人の男と交涉をもつ一人の美し い知的な女性の, 二十五年にあまる生活を描き, その特殊な立場と心理を浮彫のやうに示してみ る，心の底にかくされた心理を独白や傍白によ って示し，形式の上でも新しい境地を開いてみ る。それは近代劇—.．後の世界的傑作である と言っても過言ではない. シアター・ギルドに よって上演され，高度な藝術作品であるにかか はらず,

[ 28 ] [右半分上縁にAh, Wilderness / Days Without End と記されている]

一年六ヶ月のロングランとなってみる.

話し手三 一九三二年の「あ⿱，荒野」，翌々 三四年「限りなきいのち」を發表. それ以来，作 家として長い沈黙におちいった。

すこし前から音楽がはいってみるが， この時高まる.

話し手四一九三六年，輝かしいノーベル文学
賞が彼の頭上に輝いた.

遠く, 戰爭の行進, 飛行器の音など, 戰爭の音響，かすかに。

話し手一 第二次世界大戰. ドイツ軍のフラン スの侵入は，オニールにとって隣りの農園に 戰車のバク進してきたやうな不安をあたへた. ヨーロッパ，とくに彼の愛するフランス文化の， 戰爭によって崩れゆく様子は，彼にとって耐へ がたいことであった。

話し手二＼cjkstart彼は過去二十年にあまる作家として の活動によって，二百万ドルといふ莫大な収入 をえたと言はれてみる．当時彼はカリフォルニ アの宏荘（ママ）な農園に住んでめた

\section{[ 29 ]}

が，戰爭によって召使たちは次々と軍務に赴い た．自動車を運轉することのできないオニール 夫妻は，離れ島に打ちあげられたやうな状態に なった。

話し手三＼cjkstart精神的にも生活の上でも激しい打撃 をうけた彼は，中風症麻痺といふ病気にかか

り，六ヶ月，瀕死の病床に横は（ママ）った.

話し手四＼cjkstart戰爭の終結とともに，彼の十二年の 長い沈黙を破って，「水人來る」がニューヨー クで上演された。

話し手一 ここでは，若き日の放浪時代となじ み深い「ジミー坊主」の酒場が舞台にとられ，人 生の敗残者たちの夢と幻滅とが語られてるる.

明るい音楽が盛りあがる。

話し手二 彼は十二年の長い沈黙の間に，アメ リカの一家族の百年にわたる運命を描いた野心 作の大部分を完成したといふ.

話し手三 戰爭によって崩れさった世界の中に あって，今，彼の精神的苦悩には大きく

[ 30 ] 〔右半分上縁におそらく放送スタッフにより -23 行 / 27分40秒 と記されている]

深いものがあるにちがひない，彼はその苦悩を とほして，われわれにまた何か偉大なものを示 すにちがひないのである 


\section{付記}

以上で転写を終えた資料は，その冒頭の一葉に あるように「八月一一日 (水)」, 鉛筆による加筆 があり，また，暦でも確かめると一九四八年の夏 に放送された日本放送協会ラジオ第一放送の脚本 である。（なお，スタッフの筆跡と覚しい記入に よれば，総数 25 部のうちの一点のようである。）

この脚本が他にも所蔵される興味深い顛末を めぐる書簡などと同様，北村喜八とオニールをめ ぐる研究を推進し, また, 日本の文化がアメリカ 文化アメリカ演劇を受容し，さらには，北村が劇 場の内外を問わずオニールに取り組んでいた時代 と社会を十分に踏まえて，その文化的な実相を探 求する資料の一とされるべきことは言うまでもな い.

さらには，第二次世界大戦終了後ようやく三年 になる時期に, 当時最も伝播力の高いメディアで あったラジオ放送によるこのような企画が可能に なった事情を発掘することで，連合国占領軍によ る統治政策の一側面として、その方向性を見，戦 後日本の歩みの一端を明らかにすることにも貢献 する素材の一であろう。

資料閲覧以来すでに十年を超えるが, アメリカ の劇文学に視野を絞りがちな筆者は寡聞にして他 の言及を知らぬまま，予備的にではあれ，資料の 存在を公表することに意義があると考え, このよ
うに紹介することとした．特にオニール，その日 本における受容をめぐる考究の契機の一ともなれ ば喜ばしいと考える次第である.

\section{謝辞}

ここに紹介した資料は，畏友山本俊一氏の数度 の示唆に促されて金沢市にある石川近代文学館で 行ったオニール関連の調查中に発見した。興味深 い関連資料に混じっていたのである，氏の透徹し た博捜に敬意を表し，友情に感謝する.

短い金沢滞在中には，後にそれよりも前に同文 学館々長でもあったと聞いた井口哲郎氏にも会え, 初対面にもかかわらず，様々なご指導をいただく ことになった。 そして，埽京後には，同郷の誇り も込めて取り組みを続けられたと推察する，自身 の北村喜八研究の成果をお届けくださった。同好 の後輩を見出し喜ばれてか，資料を自由に用い発 表を進めるようにとの激励をいただきながら，報 いられないままである。慚愧に堪えない。また， 同文学館学芸員室の前多令子様，松山千津様にも 寛大かつ細やかな対応に与った。厚くお礼申し上 げる。

（受付日：2019年3月29日，受理日：2019年4月12日）

\section{山名 章二（やまな しょうじ）}

\section{大妻女子大学名誉教授}

専門はアメリカ演劇. 現在はユージーン・オニールの後期戯曲について，劇中に登場する「作家人物」 に焦点をあて，オニールの自伝的特性とからめた読み解きを行っている.

主な著作 : ユージーン・オニール 自伝と鎮魂（単著，東京，成美堂）

罪悪感をからくも逃れて一『終わりなき日々』の結末をめぐる右往左往一『人間生活文化研 究』2016, 26, 551-71 URL http://journal.otsuma.ac.jp/2016no26/2016_551.pdf 